\title{
SHALE GAS POTENTIAL OF THE LOWER CARBONIFEROUS DEPOSITS OF DNIEPER-DONETS BASIN AND NON-ANTICLINAL TRAPS
}

\section{ГАЗОСКАНЦЕВИЙ ПОТЕНЦІАЛ НИЖНЬОКАМ'ЯНОВУГІАЬНИХ ВІАКАААІВ АНІПРОВСЬКО-АОНЕЦЬКОЇ ЗАПААИНИ ТА ПАСТКИ НЕАНТИКАІНАЛЬНОГО}

\author{
Tetyana L. Popova ${ }^{1}$, Tamara M. Prigarina ${ }^{2}$, Volodymyr V. Makogon ${ }^{3}$ \\ T.^. Попова' ${ }^{1}$, Т.М. Пригаріна², В.В. Макогон ${ }^{3}$ \\ ${ }^{1}$ Limited Liability Company «Dionis line», Kyiv, Ukraine (popovatatianaleon@ukr.net) \\ ${ }^{2}$ Consulting center of Ukrainian State Geological Research Institute, Chernihiv, Ukraine (prig55@ukr.net) \\ ${ }^{3}$ Ukrainian State Geological Research Institute, Chernihiv, Ukraine (vlvIm@ukr.net)
}

The structure, lithology, paleogeography and lithofacies of Rudov Beds of the Lower Carboniferous deposits of the Dnieper-Donets Basin are being considered. The results of the present condition of Rudov Beds researches by the complex of analytical methods are being generalized. The perspectives of Lower Carboniferous deposits for the prospecting and the exploration of shale gas resources are being defined. Rudov Beds are part of Upper Visean Productive horizon V-23. They lie on limestone of the Lower Visean or on a basal silt-sandy bench. The most complete sections of the underlying Rudov Beds detrital rocks were uncovered in the submerged parts of the DDB preaxial depressions - Sviridov - Krasnozavodsk - Rudov, Chervonoluky-Harkovtsy and Solokha- Kotelva- Berezovka zones - where their thicknesses vary from 45-50 to $80 \mathrm{~m}$. They have predominantly alluvial-deltaic genesis and with a washout occur on the vesicular limestones of XIII MFH. Traps with two or more trapping elements are called combination traps (or non-anticlinal traps). Many petroleum traps have both stratigraphic and structural features. Some, in which both types of characteristics are essential in trapping petroleum, are difficult to classify as either primarily structural or primarily stratigraphic. For instance, originally horizontal formations that now pinch out updip can trap hydrocarbons that might not otherwise have accumulated. The perspectives of Lower Carboniferous deposits for the prospecting and the exploration of shale gas resources are being defined in paleogeomorphic traps (as type of combination or non-anticlinal traps). Paleogeomorphic traps are controlled by buried landscape. Some are associated with prominences (hills); others withdepression (valleys). Many are also partly controlled by unconformities so are also termed unconformity traps.

Keywords: shale gas, traps, Dnieper-Donets Basin, Lower Carboniferous deposits, lithofacies, Rudov Beds.

Розглянуто будову, літологію, палеогеографію та літофації Рудівських шарів нижнього карбону Аніпровсько-Аонецької западини. Узагальнено результати сучасного стану досліАжень Рудівських шарів комплексом аналітичних методів. Визначено перспективи нижньокам'яновугільних відкладів Аля пошуків та освоєння ресурсів сланцевого газу. Рудівські шари входять до складу верхньовізейського продуктивного горизонту В-23. Вони залягають на вапняках нижнього візе, або на базальній алевритовопісковиковій пачці. Найповніші розрізи, що піАстиляють Рудівські шари уламкових поріА розкриті у занурених частинах приосьових депресій ААЗ - Свиридівсько-Червонозаводсько-Рудівській, Червонолуцько-Харківцівській та Солохівсько-КотелевськоБерезівській зонах, Ае їх потужності варіюються віА 45-50м до 80м. Вони мають переважно алювіально-Аельтовий генезис та 3 розмивом залягають на кавернозних вапняках XIII МФГ. Пастки з Авома, або більше елементами, що їх утворили називаються комбінованими (або, так званими, неантиклінальними пастками). Чисельні вуглеводневі пастки мають як стратиграфічну, так і структурну складові особливості та риси. Аеякі з них, в яких обилва типи характеристик необхідні Аля уловлювання та утримання вуглеводнів важко класифікувати як, переважно, структурні, або, переважно стратиграфічні. НаприклаА, первинно горизонтальні пласти, котрі тепер уловлюють, можуть утримувати вуглеводні, котрі інакше не мали б змоги акумулюватись. Перспективи покладів нижнього карбону Аля пошуків та розвіАки ресурсів сланцевого газу визначаються в палеогеоморфних пастках (як типу комбінованих неантиклінальних пасток). Палеогеоморфні пастки контролюються похованим рельєфом. Аекотрі пов'язані зі здійманнями (піАняття), інші з пониженнями (западини). Багато з них, також, частково контролюються різноманітними незгіАностями та невіАповіАностями. Тому їх, також, називають пастками невідповідностей.

Ключові слова: сланцевий газ, пастки, Аніпровсько-Аонецька западина, нижньокам'яновугільні відклади, літофації, Рудівські шари.

\section{INTRODUCTION}

Lower Carboniferous black shales are widespread in Europe and occur in Central/Eastern Europe in very different tectonic positions including the Dnieper-Donets Rift Basin (DDB) (Fig. 1).

In the DDB Visean rocks are the likely source for conventional oil and gas deposits. However the Lower Carboniferous also holds a significant shale gas / shale oil / tight gas potential. The black shales have been deposited during the post-rift stage in the axial part of the DDB, where water depth probably exceeded $200 \mathrm{~m}$ only in the southeastern part of the basin.

In the sedimentary cover of most rift basins peculiar black shale rocks are presented. In the basins of Western Siberia they are known as bazhenite beds, in the Timan-Pechora province - as

(C) Tetyana L. Popova, Tamara M. Prigarina, Volodymyr V. Makogon, 2018 


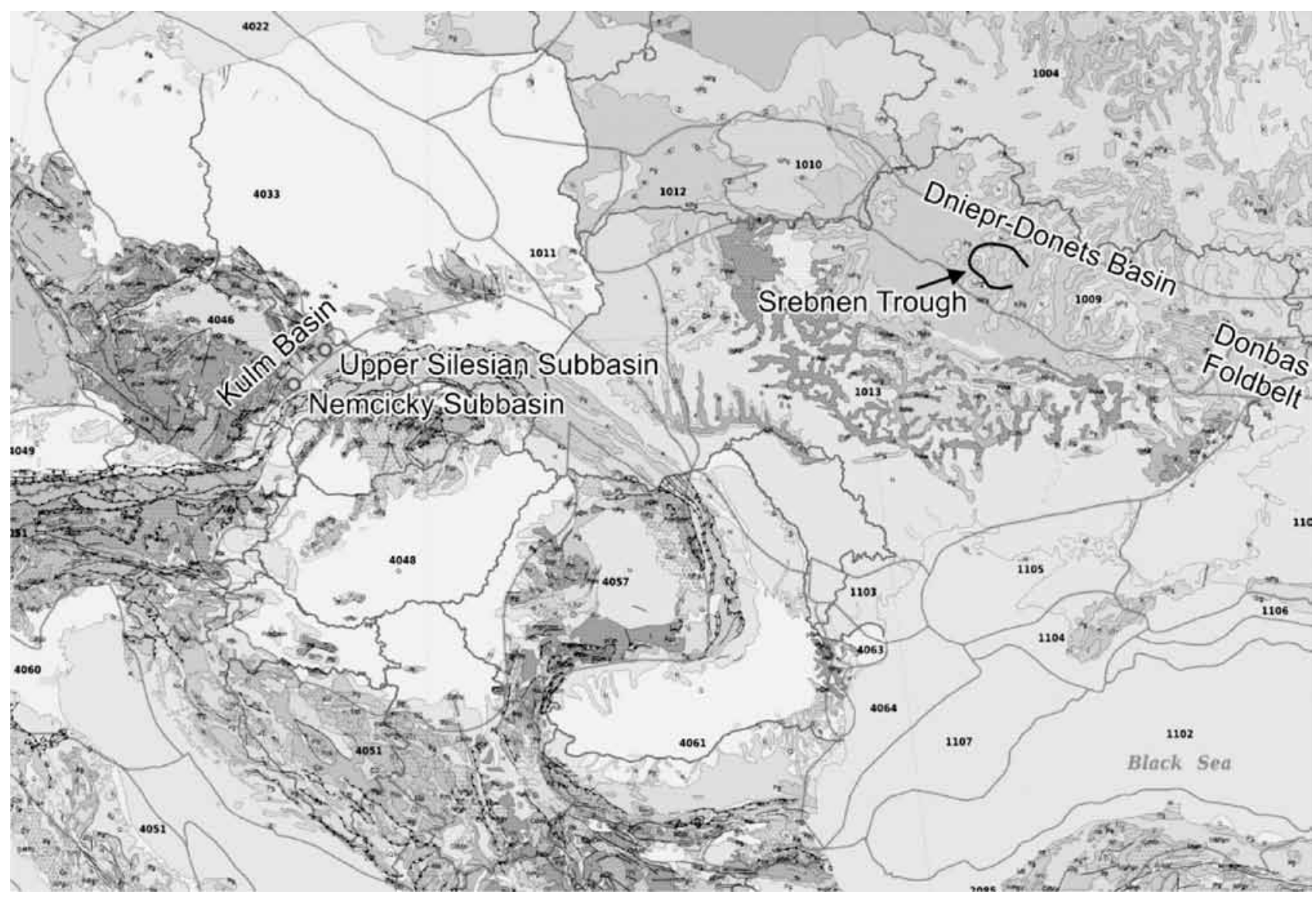

Fig. 1. Geological map of Central / Eastern Europe and position of studied basins. The location of the Srebnen Trough in the Dnieper-Donets Basin is indicated.

domanikites, in North America - as black shale formations (Chattanooga, Ohio, etc.).They're enriched with dispersed organic matter siliceous, calcareous and argillaceous rocks with carbonaceous intercalations, phosphate substance and pyrite brasses. Very often the rocks have increased radioactivity. Such strata are related to source rocks and sometimes they themselves are the subject of hydrocarbons commercial production. In the recent decades they have been attracting greater attention of geologists in connection with the prospecting for the so-called "shale gas".

In the oil and gas-bearing basins of Ukraine in this respect black shale formations of different ages containing vast resources of free and dispersed hydrocarbons are promising. Of these, the primary interest is Upper Visean formation, associated with deposits of XIla Microfaunistic horizon (MFH) Rudov Beds of the DDB.

On the larger part of the spreading area Rudov Beds (Fig. 2) are in the interval of katagenesis the most favorable for the processes of oil and gas generation (in preference mesokatagenesis stage) from stage PK3-MK1 to stage MK2-3 (R - from 0,5\% to $1,15 \%$ respectively). There are zones of "oil" and "gas" windows.

According to pyrolusis data the bituminous argillites of Rudov Beds are characterized by the next values of hydrogen index $(\mathrm{HI})$ : from $30-60$ to $140-$ 160 ; the content of organic matter (total organic content - TOC) is varied from 3 to $7 \%$. Palynologic researches of the same samples have shown a good similarity of the results.

Non-anticlinal traps (strati-structural or combination traps) are now being actively sought in the Dnieper-Donets depression. They may be present not only in the longitudian tectonic zones but also in the transverse tectonic zones, as well as in the frontal parts of negative structures.

Non-anticlinal traps result from structural deformation of rocks and stratigraphic factors both. A common example is stratigraphic pinch-out (e.g., a sandstone lans wedginginto mudstone) that is combined with tectonic tilting (which allows hydrocarbons to pond in the updip part of the sandstone wedge). Other traps result mainly from fracturing (which creates the reservoir porosity) or hydrodynamic processes. 


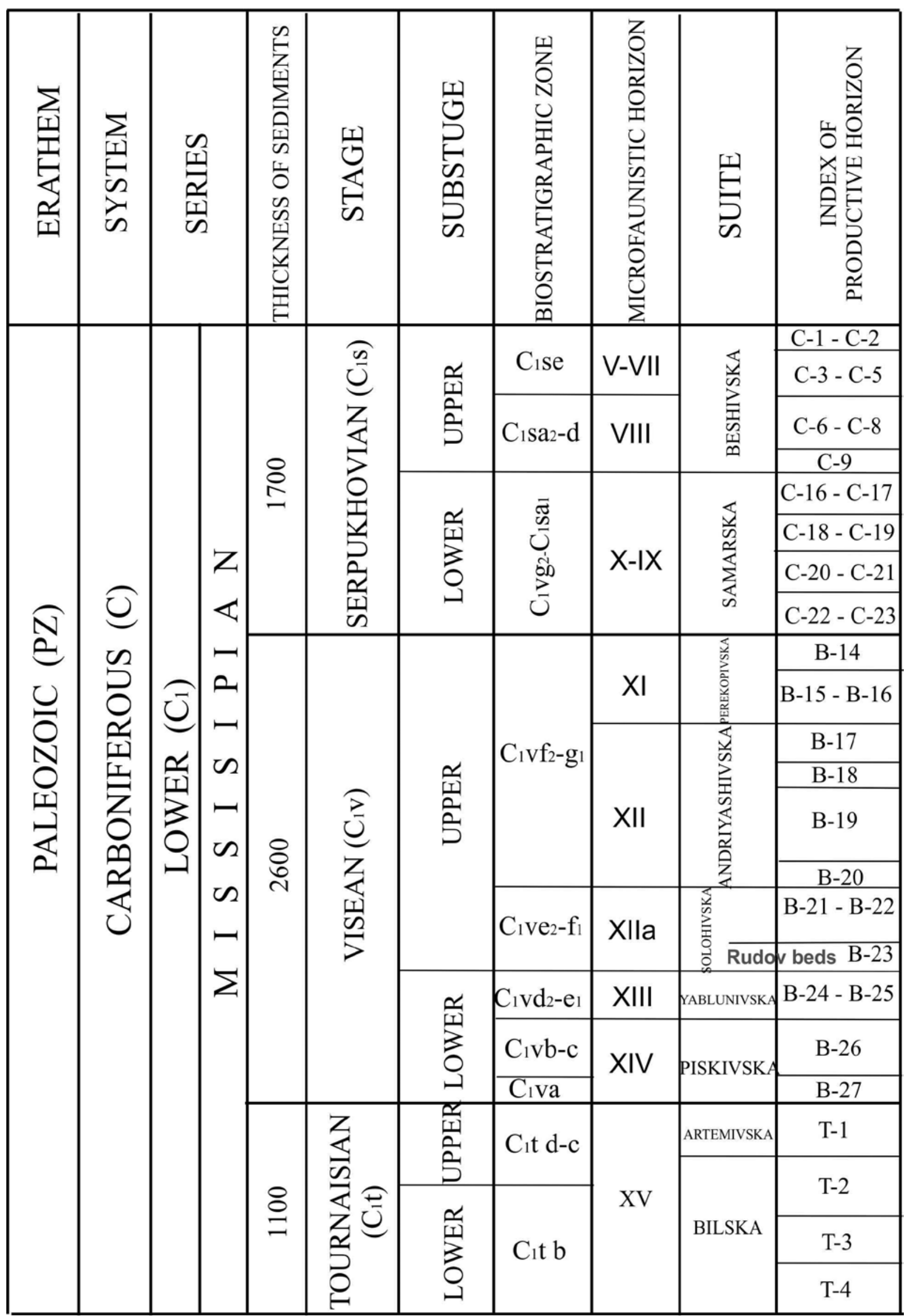

Fig. 2. Rudov Beds of Lower Carboniferous sediments stratigraphic scale (By Gozhik. P.F. etc., 2013). 


\section{GEOLOGICAL SETTING}

Previous studies (e.g. Sachsenhofer et al., 2010 cum lit.) provided a fairly good overview on the extension and organic matter richness of Lower Carboniferous sediments in the northwestern part of the DDB (Srebnen Depression). Here, TOC contents of Tournaisian, Visean and Serpukhovian rocks are often high (2-4\%) and probably controlled by sea level variations. In contrast, mainly due to the great depth, the knowledge of the shale gas potential of Lower Carboniferous (and Devonian) rocks in the central sector of the basin is still insufficient.

Shymanovskyy et al. (2004) reconstructed a complex thermal history involving relatively high Permian heat flow in the northwestern part of the DDB. Similar high Permian heat flows and a PermoTriassic heat flow event have been reconstructed for the Donbas Foldbelt (Sachsenhofer et al., 2012). Because the timing of hydrocarbon generation is largely controlled by the heat flow history, it is a major problem that the thermal history of central DDB is poorly constrained. This is especially true for the southern margin of the DDB, where Paleozoic maturity trends are preserved due to Permian uplift.

In order to study both, the organic matter richness of Lower Carboniferous rocks and the thermal evolution of the central DDB, the following boreholes have been selected for the investigations (Fig. 3, Tabl. 1):

7 wells located in the southeastern continuation of the Srebnen Depression;

4 wells located along the inverted southern basin margin, which offers a unique opportunity to study Lower Carboniferous rocks at relatively shallow depth and to reconstruct Paleozoic heat flows.

\section{MATERIALS}

As part of the Lower Carboniferous sequence - the main productive megacomplex of the Dnieper-Donets oil and gas-bearing basin - stands out for XIla MFH of the Upper Visean substage. This complex is unique to the East European Platform both by its thickness and its lithofacial composition. It's presented by polyfacial argillo-terrigene strata with thickness of a few tens of meters and less in the DDB north-western part and flanges to over $1000 \mathrm{~m}$ in the south - eastern part of its axial zone.

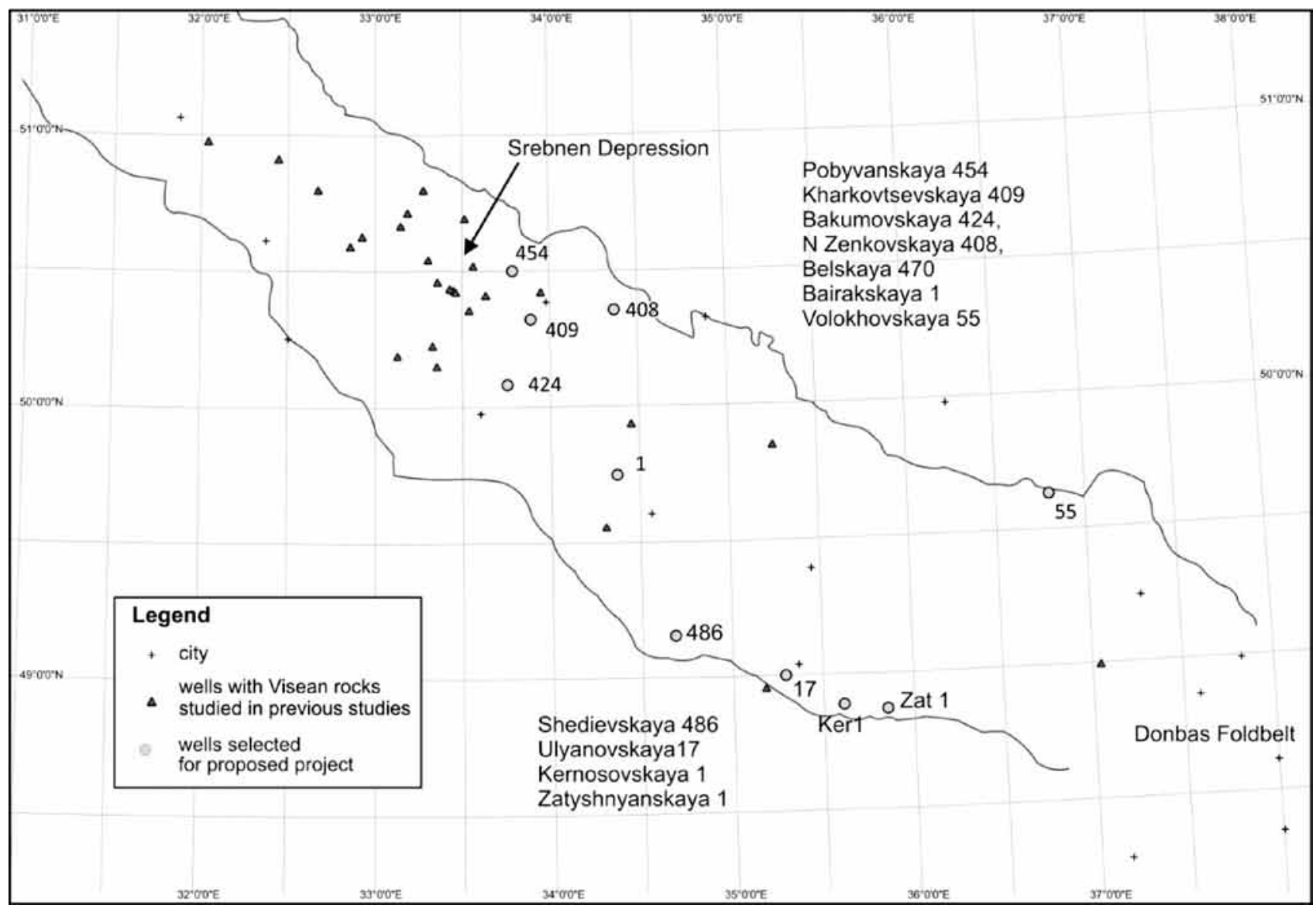

Fig. 3. Map showing locations of wells selected for the present project (yellow circles). Wells with Visean rocks studied in previous studies (Sachsenhofer et al., 2010 cum. lit.) are shown by red triangles. 
Table 1. Integrated Sampling Plan: List of wells in the DDB (basin-scale model)

\begin{tabular}{|c|c|c|c|c|}
\hline Well & Stratigraphy & Depth (m) & Maturity* & Logs \\
\hline Pobyvanskaya 454 & Tourn-Up.Visean & $4345-5099$ & immature - oil window? & GR, Res, Caliper, DT \\
\hline Kharkovtsevskaya 409 & Upper Visean & $4590-5756$ & oil - gas (?) window & GR, Res, Caliper \\
\hline Bakumovskaya 424 & Tourn-Serp. & $4170-6160$ & oil - gas (?) window & GR, Res, Caliper, DT \\
\hline N Zenkovskaya 408 & Dev-Up.Visean & $5110-5850$ & gas window? & GR, Res, Caliper, SP \\
\hline Belskaya 470 & Tour-Up.Visean & $3891-5021$ & immature - oil window & GR+DT (<4600 m), Res, Cal. \\
\hline Bairakskaya 1 & Up. Vis-Up. Serp. & $3963-5387$ & oil - gas (?) window & GR, Res, Caliper, SP \\
\hline Volokhovskaya 55 & Dev-Bashk. & $3712-5702$ & oil - gas (?) window & GR, Res, Caliper, SP \\
\hline Shediyevskaya 486 & Dev-Lo.Visean & $2720-4973$ & marginal mature-overmature & GR, Res, Caliper, DT \\
\hline Ulyanovskaya 17 & Serp. & $2265-2772$ & immature & GR, Res, Caliper, SP \\
\hline Kernosovskaya 1 & Dev-Up.Visean & $2954-4146$ & oil - gas (?) window & GR, Res, Caliper, SP \\
\hline Zatyshnyanskaya 1 & Dev-Up.Visean & $3140-4554$ & oil - gas (?) window & GR, Res, Caliper, SP \\
\hline
\end{tabular}

*(estimated using information from nearby wells.)

Deposits of XIla MFH are the product of the last phase of rifting in the DDB. Their accumulation occurred in a relatively narrow and fairly deep marine basin in terms of filling "uncompensated" depression.

To the basal part of the argillo - terrigenous XIla MFH complex is timed characteristic bench of bituminous siliceous-carbonate-argillaceous rocks (hydrocarbopellites, black shales), by name' Rudov Beds. Together these deposits constitute the characteristic domanik strata formed in the sea basin with stagnant hydrodynamic regime and periodic hydrosulphuric infection of benthic waters.

Rudov Beds are part of Upper Visean Productive horizon V-23. They lie on limestone of the Lower Visean or on a basal silt-sandy bench. The most complete sections of the underlying Rudov Beds detrital rocks were uncovered in the submerged parts of the DDB preaxial depressions - Sviridov - Krasnozavodsk Rudov, Chervonoluky-Harkovtsy and Solokha - Kotelva - Berezovka zones - where their thicknesses vary from $45-50$ to $80 \mathrm{~m}$. They have predominantly alluvial-deltaic genesis and with a washout occur on the vesicular limestones of XIII MFH.

On a number of areas (Lutsenkov, Sviridov, Mekhedov, etc.) the silty-sandy reservoirs of Productive horizon V-23 contain gas-condensate pools.

Two seams of Productive horizon V-23 - Upper and Lower belong directly to Rudov Beds. They con- tain significant amount of organic remains which allows to refer them to the deposits of Late Visean age.

One of the most significant and steady radioactive anomalies is connected with the rocks of the Lower seam. The intensity of anomalies makes up from 12 to 50 micro-roentgen / hour. The Upper seam also has often got an increased radioactivity but usually slightly smaller than the Lower ones.

In general Rudov Beds are characterized by thin horizontal and rarely by lenticular bedding marked with changes in lithologic composition. The boundaries between intercalations are expressed in different ways - from clear contacts to gradual transitions. In clay parting are often found sulphide and less often carbonaceous (Mg-siderite) concretions with different shape and size.

The total thickness of Rudov Beds in the DDB varies from $0 \mathrm{~m}$ in the extreme north-eastern part and near marginal faults up to $45-80 \mathrm{~m}$ and more in subsided parts of near-flanges zones and the axial zone.

The Rudov Beds (lowermost Upper Visean) in the Srebnen Depression are 20 to 70 m thick and contain higher TOC contents (average TOC $5 \%$ ) than any other Lower Carboniferous horizon in the study area. Therefore, they will be investigated in greater detail ("key stratigraphic horizon").

Bulk geochemical parameters and log patterns indicate that the Rudov Beds show a high vertical variability. 


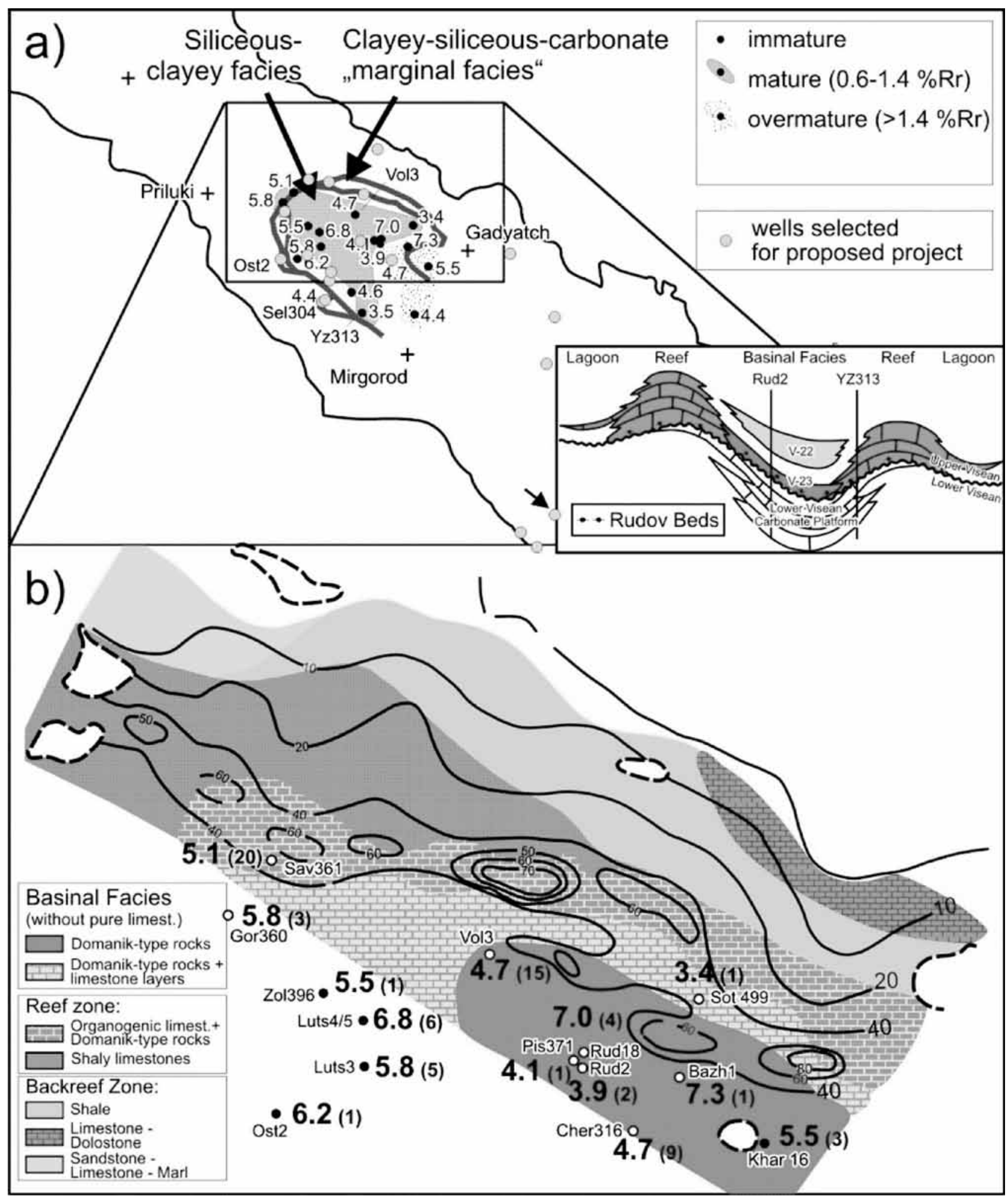

Fig. 4. Map showing the distribution of Rudov Beds in the Srebnen Trough:

a) Numbers denote mean TOC contents of Rudov Beds. Maturity of Rudov Beds in studied boreholes is indicated. Locations of wells selected for the present project are shown by yellow circles;

b) Facies of Rudov Beds in the northern part of the Srebnen Trough. Isolines indicate thickness of Rudov Beds (in m). Numbers denote mean TOC contents. Numbers in parentheses indicate the sample number. 
Table 2. Integrated Sampling Plan: List of wells in the DDB (reservoir-scale model)

\begin{tabular}{|c|c|c|c|c|}
\hline Well & Stratigraphy & Depth (m) & Maturity* & Logs \\
\hline Ostapovskaya 2 & Rudov & $3840-3857$ & immature? & GR, Res, Caliper, SP \\
\hline Selyukhovskaya 2 & Rudov & $3204-3223$ & immature & GR, Res, Caliper, SP \\
\hline Selyukhovskaya 304 & Rudov & $3116-3126$ & immature & GR, Res, Caliper, DT \\
\hline Yantarnaya 387 & Rudov & $5154-5226$ & oil window? & GR, Res, Caliper \\
\hline Kharkovetskaya 409 & Rudov & $5756-5787$ & gas window? & GR, Res, Caliper, SP \\
\hline Prirechnaya 1 & Rudov & $5240-5254$ & oil window? & GR, Res, Caliper, SP \\
\hline Rechnaya 386 & Rudov & $5658-5673$ & oil window & GR, Res, Caliper, SP \\
\hline Golotovshchinskaya 2 & Rudov & $5239-5270$ & oil window? & GR, Res, Caliper, SP \\
\hline Bubyrkovskaya 1 & Rudov & $4831-4874$ & oil window? & GR, Res, Caliper, SP \\
\hline W Aleksinskaya 1 & Rudov & $5583-5608$ & gas window & GR, Res, Caliper, SP \\
\hline Vel. Bubn. 317 & Rudov & $3310-3330$ & immature & GR, Res, Caliper, DT \\
\hline Voloshkovskaya 314 & Rudov & $5049-5058$ & immature - oil window? & GR, Res, Caliper, SP \\
\hline N Pogarshchinskaya 389 & Rudov & $5075-5103$ & oil window? & GR, Res, Caliper \\
\hline Kampanskaya 2 & Rudov & $4910-4953$ & oil window & GR, Res, Caliper, SP \\
\hline Krasnozavodskaya 3 & Rudov & $5410-5459$ & oil window & GR, Res, Caliper, SP \\
\hline Martinovskaya 450 & Rudov & $4563-4567$ & immature & GR, Res, Caliper, SP \\
\hline Belskaya 470 & Rudov & $4456-4469$ & oil window? & Res, Caliper \\
\hline Solokhovskaya 49 & Rudov & $4867-4886$ & oil window & GR, Res, Caliper, SP \\
\hline Gorobtsovskaya 12 & Rudov & $4417-4488$ & oil window & GR, Res, Caliper, SP \\
\hline Boyarskaya 1 & Rudov & $2857-2906$ & immature & GR, Res, Caliper, SP \\
\hline Chapaevskaya1 & Rudov & $2180-2190$ & immature & GR, Res, Caliper, SP \\
\hline Mazharovskaya 493 & Rudov & $5116-5142$ & oil - gas window?? & GR, Res, Caliper, DT \\
\hline
\end{tabular}

*(estimated using information from nearby wells).

Moreover they represent different lateral facies zones (shaly siliceous to carbonate-rich). Based on facies studies, it was discussed that the high TOC contents in the Srebnen Depression (Fig. 4) may be due to a special paleogeographic setting ("Srebnen mega-atoll" characterized by limited water exchange). The maturity varies from immature to gas window maturity (Fig. 4).

In the proposed study, we plan to investigate Rudov Beds with different maturity within and out- side the Srebnen mega-atoll. In a first step, logs from 20 wells (Table 2; see Fig. 4a for location) will be used for the investigation of log facies and for well log correlations.

Based on vertical and lateral log facies variations (and considering results from previous studies), the most suitable core material will be selected and studied using a high resolution approach (approximately 1 sample / meter). 
According to Sachsenhofer et al. (2010), TOC variations in Rudov Beds are largely independent from the position of the wells in distinct facies zones. Moreover, there is an apparently poor correlation between gamma readings and TOC contents. To study this phenomenon in detail (and to determine core to log shift), we will test the applicability of spectral core gamma investigations.

Traps with two or more trapping elements are called combination traps.

Many petroleum traps have both stratigraphic and structural features. Some, in which both types of characteristics are essential in trapping petroleum, are difficult to classify as either primarily structural or primarily stratigraphic. For instance, originally horizontal formations that now pinch out updip can trap hydrocarbons that might not otherwise have accumulated. Secondary porosity in a shattered (brecciated) fault zone or anticlinal crest is a stratigraphic trapping mechanism caused by structural deformation. Most hydrodynamic trapping depends partly upon formation structural features and often upon stratigraphic variations within the reservoir formation.

Many types of traps can be found near salt domes. Most would be considered structural, although some could be classified as combination traps. Beneath the U.S. Gulf Coast are thick beds of salt that were deposited, during the opening of the modern Atlantic Ocean, in sedimentary basins with restricted circulation and high evaporation rates. Under pressure, this rock salt, light and easily deformed, is displaced by the weight of accumulating sediments, forming huge mushroom-like columns that rise toward the surface. In each of these diapirs, the overlying rocks are pushed aside or bulged upward into a dome. The penetrated layers are dragged upward by the rising salt core and depressed downward away from it as the overlying layers subside to replace the depleted salt bed. Leaching by groundwater prevents the salt from breaking through the surface, but leaves atop the column a residue of less soluble compounds, forming a dense, impermeable caprock. Overlying sediments break in a complex series of intersecting faults. The base of the salt core may narrow, creating a mushroom-shaped overhanging column.

Many types of petroleum traps are thus formed: a multi-layered dome on top, cut by faults; upturned drag folds that terminate against impermeable salt; upturned pinchouts where compression and other diagenetic changes have reduced permeability; and faults along the flanks. Oil may also collect beneath the impermeable caprock or beneath the overhanging salt. The multiple possibilities for traps and the high likelihood of finding petroleum have made salt domes popular places to drill.

\section{METHODS}

a) Paleogeographic environment of Rudov Beds formation is as follows. One of the largest on the territory of the East European Platform, the Urals, the Donbass and the DDB the transgression of the sea basin was completed in the late Early Visean time by its regression and washout of XIII MFH XIII MFH carbonaceous and argillo-carbonaceous sediments.

At the beginning of the Late Visean time (XIla MFH) on the territory of the DDB a new cycle of sedimentation began which was associated with another tectonic settling of the region. First on the washed out surface of the Lower Visean predominantly carbonate complex, poorly differentiated clastic material was being evacuated by fluvial streams. It was filling channels of the Early Visean relief (alluvial channels and deltaic ones) forming the series of basal terrigenous beds.

Further development of the transgression led to the formation of a broad depressional sea basin of euxinic type with prevailing stagnant hydrological regime in which bituminous argillo-carbonaceous sediments of the Productive horizon V-23 (Rudov Beds) were being deposited .

Overall peneplanation of the removal area and relatively quiet tectonic regime for a long period of time predetermined a slight removal of terrigenous material. Following the regression the near-shore areas have been turned into a swamped lowland where some organic matter was being actively accumulated. During the transgression it found itself within the basin waters where partially was immediately buried and partly returned to the biological cycle causing a splash of bioproductivity. As a result, this led to unoxygenous conditions, the accumulation and burial of new portions of organic matter and the formation of black shales layers. The accumulation occurred in the troughs of the sea bottom with a quiet environment in the central parts of the paleo-basin at depths of $300-500 \mathrm{~m}$. The attenuation of the erosional land-based activity led to uncompensated disposition of sedimentation.

Biosedimentation processes played a leading role and a decisive factor of the deposition and accumulation of elements was a geochemical environment of the basin. It was determined primarily by the abundant accumulation of the dying phyto- 


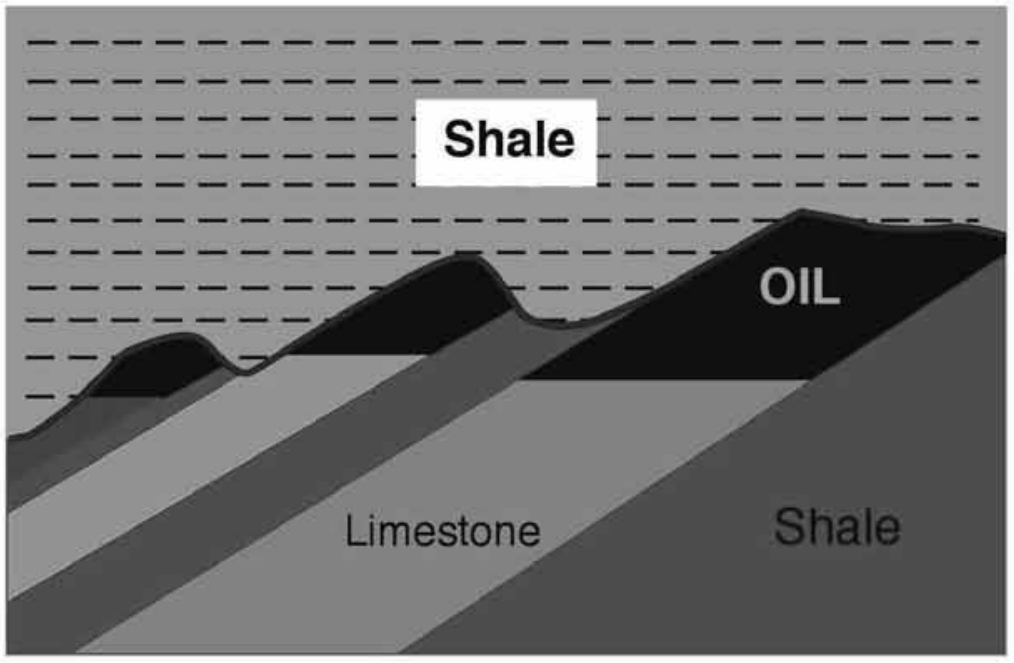

\section{Oil trapped below unconformity in paleotopographic highs below transgressive shales}

\section{Oil trapped above unconformity in paleotopographic lows formed by porous channel sands}

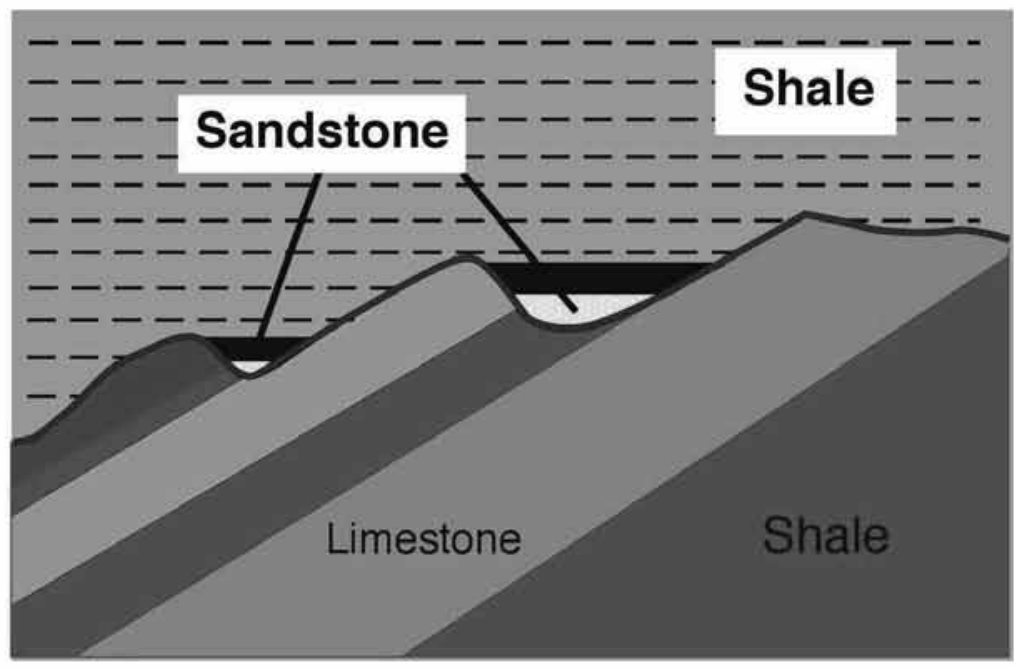

Fig. 5. Paleogeomorphic traps of Lower Carboniferous deposits.

plankton whose decomposition has dramatically provided restorative unoxygenous environment of benthic silt waters and their hydrogen sulphide contamination. Formed during diagenesis phosphate, siliceous and organic colloids due to their high ionexchange capacity sorbed a number of small elements from silt waters including radioactive.

b) Lithofacies. Rudov Beds refer to facia of siliceous-carbonate-argillaceous bituminous deposits of depression areas of the sea basin with anoxic regime. In the section they are occured on the lagoon-flooded and sea argillaceous or carbonaceous deposits and overlapped by polyfacial formations of marine origin. Laterally, these deposits are replaced by shoaly-shelf and near-shore-marine terrigenous or carbonaceous rocks .

The massive bituminous argillites with uniform texture and bituminous microlaminated (foliated) ar- gillites are dominated in the section. The foliation is predominantly caused by the alternation of dissimilar in composition, structure and competence of laminas separately enriched by pelitic, aleuritic, siliceous and carbonaceous material as well as bituminous matter.

These are black (brownish-black, dark gray) pelitomorphic hydrophobic rocks, quite similar to "bituminous shales" of Ohio (Big-Sandy field). They are characterized by wide variations in ratios of organic matter with argilleceous, as well as siliceous, carbonaceous, phosphate and disulfide-ferrous (abundance of framboid pyrite) material, micro-layered textures (with broad development of foliaceous variations). The content of organic matter varies from $2,5-5$ to $14-16 \%$ ( $C_{\text {ors }}$ - from $1,5-3$ to $6-8 \%$ and more). Kerogen is mixed of humic-sapropel type. The value of $b^{13} \mathrm{C}$ is $-27+28 \%$ which is similar to bazhenites of Western Siberia. The content of chlo- 
roform bitumen in rock varies from 0,015 to $0,35 \%$ (while the oil content amounts to 37-55\%) reaching maximum values in packs (radioactive datum mark) of the lower section part most enriched with organic matter. The latter, given significant post-sedimentary organic losses, were initially similar to sapropelites.

\section{RESALTS AND PROSPECTS}

Up-to-date processes of hydrocarbon generation are proved by a number of features, including their chemical-bituminological and mineralogical (presence of "live" organo-smectite complexes) peculiarities, presence among deposits of abnormal "gas-vapour" systems - deposits of critical state, occurrence of AHRP (Abnormally High Reservoir Pressure), etc. This provides a constant inflow of hydrocarbons into the deposits confined to sandy reservoirs of XIla MFH, as well as Lower Visean carbonaceous reservoirs paragenetically related to them (Kampansk, Lipovodolinsk and other fields). Their scale is explained by purely tentative calculations in the inside part the most long-term as for Rudov Beds of Srebnenska depression within the area of $1105 \mathrm{~km}^{2}$ disposed in the DDB north-western part.

Taking the average thickness of black shales within its range of $100 \mathrm{~m}$, average concentrations of liquid and gaseous hydrocarbons of $50 \mathrm{mg} / \mathrm{kg}$

\section{REFERENCES}

Francu E., Francu J., Kalvod J., Poelchau H.S., Otava J., 2002. Burial and uplift history of the Paleozoic Flysch in the Variscan foreland basin (SE Boemian Massif, Czech Republic). EGU Stephan Mueller Special Publication Series, 1, pp. 167 179. (In English).

Gozhik. P.F. etc., 2013. Stratigraphy of Upper Proterozoic and Phanerozoic of Ukraine in two volumes. Vol.1: Stratigraphy of Upper Proterozoic, Paleozoic and Mesozoic of Ukraine, 638 p. (In Ukrainian).

Lukin O. Y., 2010. Shale gas and perspective of its production in Ukraine. Article 1. Current status of shale gas (in the light of experience of resources exploration in USA). Geological journal.. №3, pp. 17-32. (In Russian).

Lukin O. Y., 2010. Shale gas and perspective of its production in Ukraine. Article 2. Black-shale complex of Ukraine and gas-bearing perspectives of Volyno-Podolya and south-west Black-sea-coast-region. Geological journal. №4, pp. 7-24. (In Russian).

Makogon V.V., Goncharov G. G., Prigarina T.M., Kryvosheev V.T., Popova T.L. and etc, 2014. Regional characteristic of oil-maternal rocks of Rudov beds Lower Carboniferous deposits DDB, pp. 1-53. (In Ukrainian). and $50 \mathrm{~cm}^{3} / \mathrm{kg}$ respectively, average volume density of black shales $2 \mathrm{~g} / \mathrm{cm}^{3}$, we obtain based on elementary calculations nearly 500 million tons of liquid hydrocarbons and about 1,5 trillion $\mathrm{m}^{3}$ of gaseous hydrocarbons).

The perspectives of Lower Carboniferous deposits for the prospecting and the exploration of shale gas resources are being defined in paleogeomorphic traps (as type of combination traps).

Paleogeomorphic traps are controlled by buried landscape. Some are associated with prominences (hills); others withdepression (valleys). Many are also partly controlled by unconformities so are also termed unconformity traps (Fig. 5).

\section{CONCLUSION}

The fulfilled researches of the peculiar sedimentary complex of the DDBasin of Rudov Beds (carbonateargillaceous strata) testify to their high perspectivity for the prospecting of shale gas. However, the solution of the problem of the prospecting $\mathrm{HC}$ unconventional accumulations requires additional researches. In order to estimate the resources potential and the definition of the prospecting parameters of shale gas in Upper Visean of the DDB we have announced our participation in the European project GASH-II.

Francu E. Burial and uplift history of the Paleozoic Flysch in the Variscan foreland basin (SE Boemian Massif, Czech Republic) / Francu, E., Francu, J., Kalvoda, J., Poelchau, H.S., Otava, J. - EGU Stephan Mueller Special Publication Series, 2002. - 1. - 167-179 p.

Стратиграфія верхнього протерозою та фанерозою України [Текст]: у 2 т. / Ін-т геол. наук НАН України. - Київ: ІГН НАН України: ^огос, 2013. Т. 1 Стратиграфія верхнього протерозою, палеозою та мезозою України / [П. Ф. Гожик та ін.] ; голов. реА. П. Ф. Гожик. - 2013. - 636 с.

^укин А.Е. Сланцевый газ и перспективы его Аобычи в Украине. Статья 1. Современное состояние проблемы сланцевого газа (в свете опыта освоения его ресурсов в США) / ^укин А.Е. - Геологический журнал - 2010. - №3. 17-32 c.

Аукин А.Е. Сланцевый газ и перспективы его добычи в Украине. Статья 2. Черносланцевые комплексы Украины и перспективы их газоносности в Волыно-Подолии и СевероЗападном Причерноморье / Лукин А.Е. - Геологический журнал - 2010. - №4. - 7-24 с.

Макогон В.В. Регіональна характеристика нафтоматеринських поріА Рудівських шарів нижнього карбону ААЗ / Макогон В.В., Гончаров Г.Г., Кривошеєв В.Т., Пригаріна Т.М., Попова Т. ^. та ін. - (2014), Чернігів: УкрАГРІ. - 2014 1-53 c. 
Makogon V., Goncharov G., Lukin O., Sachsenhofer R.F., Popova T, 2014. Rudov Beds as a main object of shale gas prospecting in the Lower Carboniferous of the Dnieper-Donets Basin (Netherland, Amsterdam, EarthDoc EAGE'S online geoscience, WE P08 03. (In English).

Sachsenhofer R.F., Privalov V.A., Panova E.A., 2012. Basin evolution and coal geology of the Donets Basin (Ukraine, Russia): An overview. Int. J. Coal Geol. 89, pp. 26-40. (In English).

Sachsenhofer R.F., Shymanovskyy V.A., Bechtel A., Gratzer R., Horsfield B., Reischenbacher D. (2010) Paleozoic Source Rocks in the Dnieper-Donets Basin (Ukraine). Petroleum Geoscience, 16, pp. 377-399. (In English).

Shymanovskyy V.A., Sachsenhofer R.F., Izart A., Li Y., 2004. Modelling of the thermal evolution of the northwestern Dnieper-Donets Basin (Ukraine). Tectonophysics, 381, pp. 61-79. (In English).

Manuscript received November 1, 2018; revision accepted November 20, 2018
V. Makogon Rudov Beds as a main object of shale gas prospecting in the Lower Carboniferous of the Dnieper-Donets Basin / V. Makogon, G. Goncharov, O. Lukin, R.F. Sachsenhofer, T. Popova - Netherland, Amsterdam, EarthDoc EAGE's online geoscience, - 2014. - WE P08 03.

Sachsenhofer R.F. Paleozoic Source Rocks in the DnieprDonets Basin (Ukraine) / Sachsenhofer R.F., Shymanovskyy V.A., Bechtel A., Gratzer R., Horsfield B., Reischenbacher D. Petroleum Geoscience, - 2010. - 16. - 377-399 p.

Sachsenhofer R.F. Basin evolution and coal geology of the Donets Basin (Ukraine, Russia) / Sachsenhofer R.F., Privalov V.A., Panova E.A. - An overview. Int. J. Coal Geol. 89 - 2012. 26-40 p.

Shymanovskyy V.A. Modelling of the thermal evolution of the northwestern Dniepr-Donets Basin (Ukraine) / Shymanovskyy, V.A., Sachsenhofer, R.F., Izart, A., Li Y. - Tectonophysics - 381. - $2004-61-79$ p.

ТОВ "Аіоніс майн", Київ, Україна Український Аержавний геологорозвідувальний інститут, Чернігів, Україна Український Аержавний геологорозвідувальний інститут, Чернігів, Україна

\section{ГАЗОСААНЦЕВЫЙ ПОТЕНЦИАЛ НИЖНЕКАМЕННОУГОЛЬНЫХ ОТАОЖЕНИЙ АНЕПРОВСКО-АОНЕЦКОЙ ВПААИНЫ И АОВУШКИ НЕАНТИКАИНААЬНОГО ТИПА}

\section{Т.^. Попова, Т.М. Пригарина, В.В. Макогон}

Рассмотрено строение, литология, палеогеография и литофации Рудовских слоев нижнекаменноугольных отложений Анепровско-Аонецкой впадины. Обобщены результаты современного состояния изученности Рудовских слоев комплексом аналитических методов. Определены перспективы нижнекаменноугольных отложений Аля поисков и освоения сланцевого газа. Рудовские слои входят в состав верхневизейского продуктивного горизонта В-23. Они залегают либо на известняках нижнего визе, мибо на базальной алевритово-песчаной пачке. Наиболее полные разрезы подстилающих Рудовские слои обломочных пород вскрыты в погруженных частях приосевых депрессий ААВ - Свиридовско-Краснозаводско-Рудовской, Червонолукско-Харьковцевской и Солоховско-Котелевско-Березовской зонах, гАе их мощности варьируются от 45-50 до 80м. Они имеют, преимущественно, аммювиально-дельтовый генезис и с размывом залегают на кавернозных известняках XIII МФГ. Аовушки с Авумя и больше элементами, которые их образовали, называются комбинированными (или, так называемыми, неантиклинальными ^овушками). Многие ловушки углеводородов имеют и стратиграфическую, и структурную составляющую. Некоторые из них, в которых оба типа характеристик необходимы для улавливания и удерживания углеводородов тяжело классифицировать, как, преимущественно, структурные, или, преимущественно, стратиграфические. Например, изначально горизонтальные пласты, которые в данное время улавливают, могут и удерживать углеводороды, которые, которые иначе могли бы не накапливаться. Перспективы залежей нижнего карбона Аля поиска и разведки ресурсов сланцевого газа определяются в палеогеоморфных ^овушках (как тип комбинированных ^овушек или неантиклинальных ^овушек). Палеогеоморфные ^овушки контролируются погребенным ландшафтом. Некоторые связаны с подъемом (поднятия); другие с понижением (впадины). Многие из них также частично контролируются несоответствиями, поэтому их также называют ловушками несоответствий.

Ключевые слова: сланцевый газ, ловушки, Анепровско-Аонецкая впадина, нижнекаменноугольные отложения, литофации, Рудовские слои. 